\title{
Desalination Processes and Performance
}

\section{Summers}

June 1995

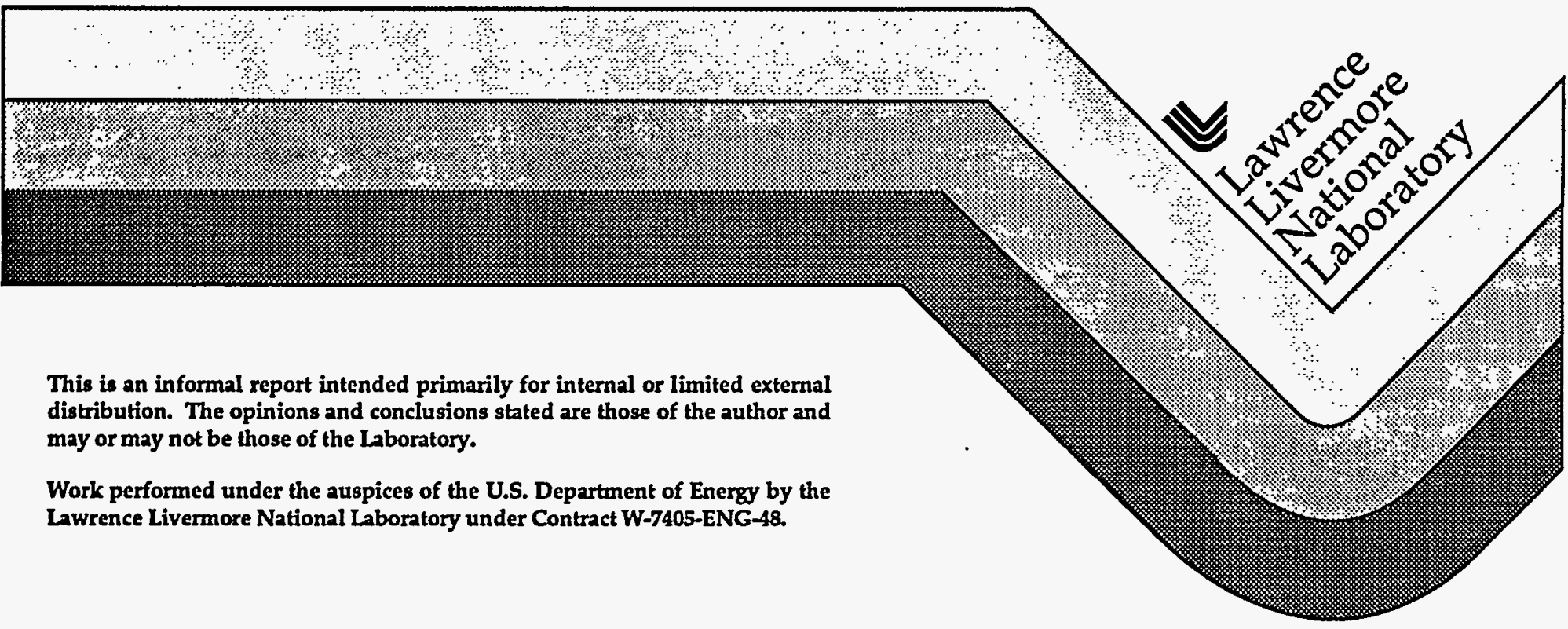




\section{DISCLAIMER}

This document was prepared as an account of work sponsored by an agency of the United States Government. Neither the United States Government nor the University of California nor any of their employees, makes any warranty, express or implied, or assumes any legal liability or responsibility for the accuracy, completeness, or usefulness of any information, apparatus, product, or process disclosed, or represents that its use would not infringe privately owned rights. Reference herein to any specific commercial product, process, or service by trade name, trademark, manufacturer, or otherwise, does not necessarily constitute or imply its endorsement, recommendation, or favoring by the United States Government or the University of California. The views and opinions of authors expressed herein do not necessarily state or reflect those of the United States Government or the University of California, and shall not be used for advertising or product endorsement purposes.

This report has been reproduced directly from the best available copy.

Available to DOE and DOE contractors from the Office of Scientific and Technical Information P.O. Box 62, Oak Ridge, TN 37831

Prices available from (615) 576-8401, FIS 626-8401

Available to the public from the National Technical Information Service

U.S. Department of Commerce 5285 Port Royal Rd., Springfield, VA 22161 


\title{
Desalination Processes and Performance
}

\author{
Leslie J. Summers \\ Lawrence Livermore National Laboratory
}

Throughout time man has used fresh water for drinking, industrial, and agricultural purposes, and has settled where suitable water was available. The rapid increase of the world's population and the nonuniform distribution of fresh water around the world has motivated research into the development of desalination methods. If pure water could be economically obtained from sea water it would have a dramatic affect on our future standard of living, as competition for fresh water increases. Progressive industrialization and expansion of irrigation agriculture add to the ever increasing use of fresh water. Until now, we have been paying a low price for fresh water, however the cost may increase dramatically as demand increases and we are forced to use other methods to avail ourselves of fresh water.

Desalination of sea water offers great potential for increasing the availability of fresh water. The salinity of sea water can be reduced by a number of approaches such as distillation, reverse osmosis or electrodialysis. The most suitable process depends upon the ultimate use and availability of resources. For example, sea water conversion using evaporative distillation is usually built on the shore and combined with a power generation plant using fossil or nuclear energy to produce water suitable for agricultural needs (very low salinity). Electrodialysis and reverse osmosis systems will not yield suitable water for agriculture but are more flexible in location and can efficiently treat reservoirs of brackish water (BW). The success of each approach depends upon the required capital investment, capacity, operation and maintenance costs for the particular application. The cost of desalting water is made of two major components, capital and operating costs.

Fixed or capital costs include:

\author{
Land costs \\ Labor \\ Working capital and interest \\ Site development, roads, buildings \\ Desalting equipment \\ Brine disposal \\ Water pre/posttreatment
}

Operating Costs:

Operation \& Maintenance

Spares, supplies, maintenance manpower

Chemicals

Membrane replacement (RO and Electrodialysis)

Power

To date, there is no desalination process which is a clear winner. For evaporative distillation, the major capital costs are the heat transfer areas, containment shell, pumps and piping. The major operating costs are dominated by costs for steam, labor, chemicals and power for pumping. Electrodialysis (ED) and Reverse Osmosis (RO) have lower energy costs than evaporation but provide less efficient separation of sea water. They are more suited for purification of brackish water. ED is less expensive to purchase and install than RO, but more costly to operate. Overall costs for a desalination plant are quite site specific and local costs can be very important. The selection of a particular process and design is made considering the above expenses and optimizing the system to produce the desired quantity and quality of water at the lowest cost.

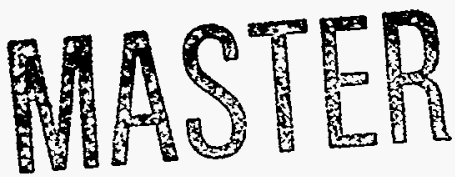




\section{Desalination:}

Sea water contains dissolved salts at a concentration of $\sim 35,000 \mathrm{ppm}$, and brackish water $\sim 10,000 \mathrm{ppm}$. These levels must be reduced to $\sim 500 \mathrm{ppm}$ for drinking water, and to $\sim 50 \mathrm{ppm}$ for agricultural use. Achieving the separation of water or salt from solutions of salt must be forced to occur and requires energy. For example, when salt water is evaporated, energy is input then recovered in condensation of the vapor to water. The vapor must be cooled or slightly compressed. For sea water this energy amounts to about 2.8 $\mathrm{kwh} / 1000$ gal of product at $77 \mathrm{C}{ }^{1}$ This reflects the minimum energy required for operation with no inefficiencies. Current processes require more than the minimum. In fact, about four times the thermodynamic minimum is the best obtainable to date. ${ }^{23}$ The thermal efficiency or performance of a desalination process is normally stated as the ratio of water produced to the required heat input. This relationship is usually expressed as the "performance ratio" or "economy", defined as the pounds of distillate produced per $1000 \mathrm{Btu}$ of heat input.

\section{Distillation Processes:}

Distillation is the oldest and most commonly used method of desalination. It is the major source of fresh water for the Middle East. Early designs were of the multieffect $(M E)$ submerged tube type. Steam is fed through tubes submerged in a pool of brine, causing the brine to evaporate. The vapors produced, which are pure and free from any salts, are then condensed, yielding clean water. Salts remain behind and the sea water becomes more concentrated. The high temperatures required and subsequent evaporator tube scaling due to increasing salt concentrations cause major problems in this method. Subsequently, several techniques have been developed to improve the efficiency of evaporative distillation. The most widely used is multistage "flash" evaporation (MSF) See figure 1.

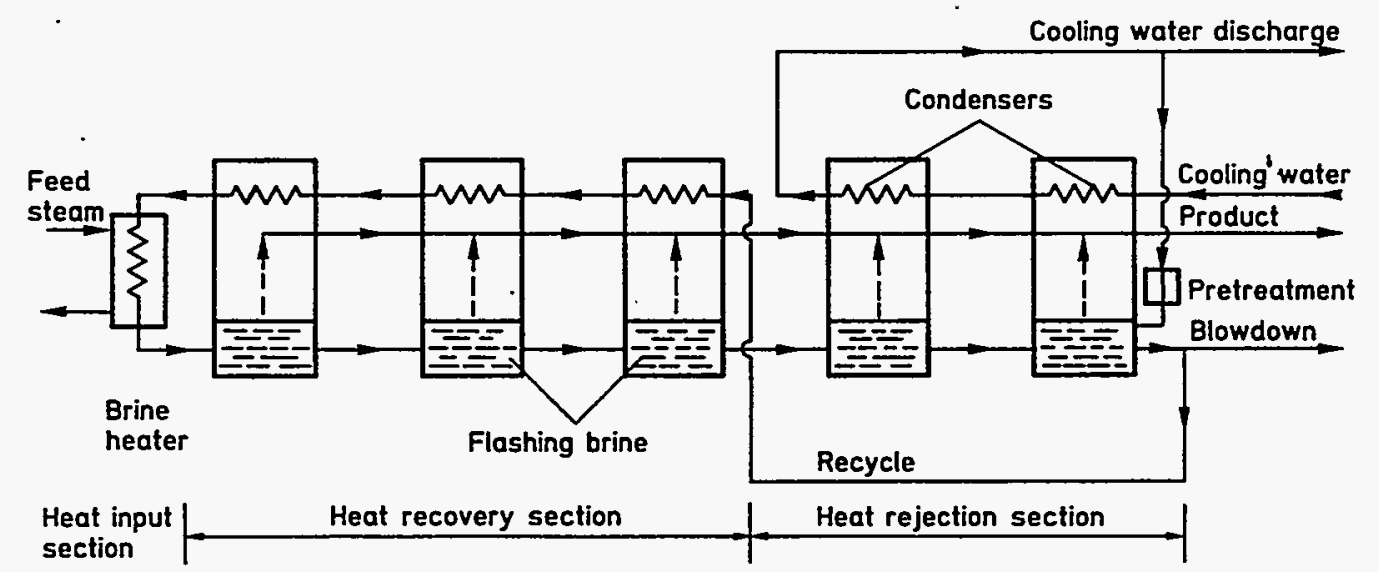

Fig. 1. Multi-stage flash distillation

Vapor can be produced from a liquid at it's boiling point by either adding more heat (boiling) or by reducing the pressure (flashing). When the pressure is reduced, the temperature also decreases. The amount of energy which can be stored in water (at its boiling point) decreases as the pressure is reduced. In MSF, water is brought into a chamber sufficiently low in pressure, to cause the water to "flash" evaporate. The water continues to evaporate until equilibrium with the lowered pressure is reached Product water is condensed and transported away. Evaporation lowers the temperature of the remaining brine. Several stages, at subsequently lower pressures, reduces the amount of heat that has to be removed from the process. 
The number of stages controls the amount of heat recovery possible and determines the amount of external energy that must be supplied. The overall efficiency is dramatically improved. In addition, MSF has less scale formation than conventional distillation because of the flash evaporation and lower temperature. A second process is "vapor compression distillation". Sea water is preheated in an MSF unit. The vapors produced are then compressed by a compressor attached to the evaporator. The compressed vapors are returned to the evaporator where they are used as a heat source to the incoming sea water. The vapor loses its latent heat to the incoming sea water and condenses yielding clean product water. The temperature differences between evaporation and condensation are fairly small, 4-5 degrees, minimizing energy consumption and scale formation.

\section{Membrane Processes:}

Reverse osmosis is a separation processes which uses membranes to selectively remove water from salt water. In conventional osmosis, water or solvent flows through a semipermeable membrane from a less concentrated solution to an area of higher concentration (see fig 2).

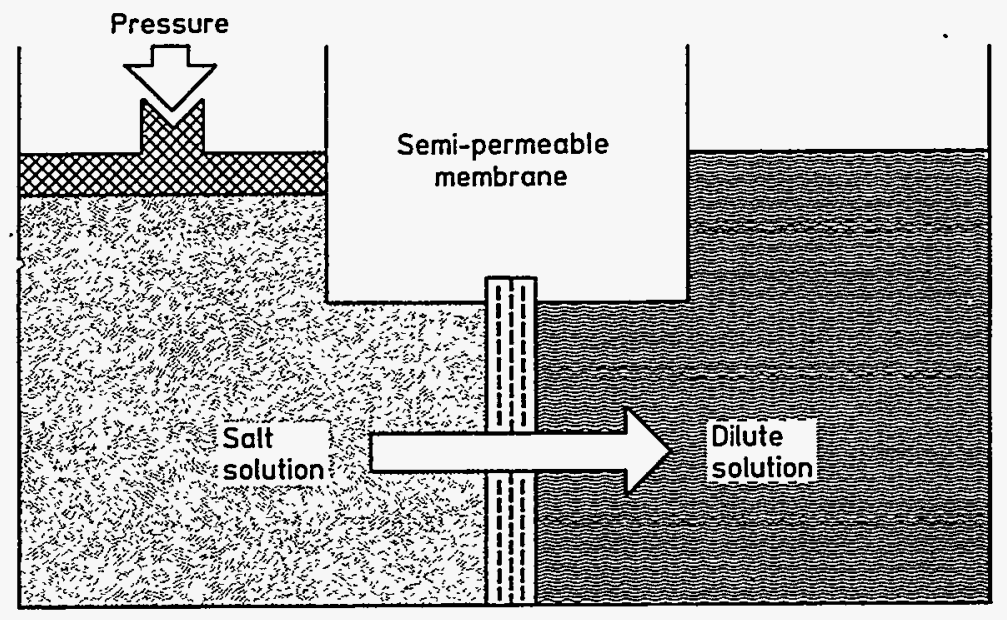

Fig. 2. Principles of reverse osmosis

This normal osmotic flow can be reversed with the application of pressure to the more concentrated solution. The applied pressure must be in excess of the normal osmotic pressure $(-25 \mathrm{~atm})$. In desalination, sea water is pretreated, filtered and pumped at high pressure through the semi-permeable membranes. The membranes composed of either cellulose acetate or polyamide, are typically assembled in modules, in either a plate and frame, tubular or spiral configuration. An RO system usually consists of several modules connected together. The processed feedwater is separated into two streams, with the permeate passing through the membranes due to the pressure, while the remaining concentrated salt brine is continuously rejected. Because energy in the form of heat is not required, this process can operate at ambient temperature without the associated high temperature problems associated with distillation. The concentrated brine must be continuously removed due to the 2-4 fold increases in concentration at the membrane. Over time, accumulation of concentrated salts will result in scale formation, plugging of the membrane and reduced water flux. Pretreatment of the feedwater is necessary to prevent scale formation and biological attack of the membranes. 
Electrodialysis utilizes an electrochemical cell which contains alternating anion and cation exchange membranes, arranged between an anode and cathode (see fig. 3).

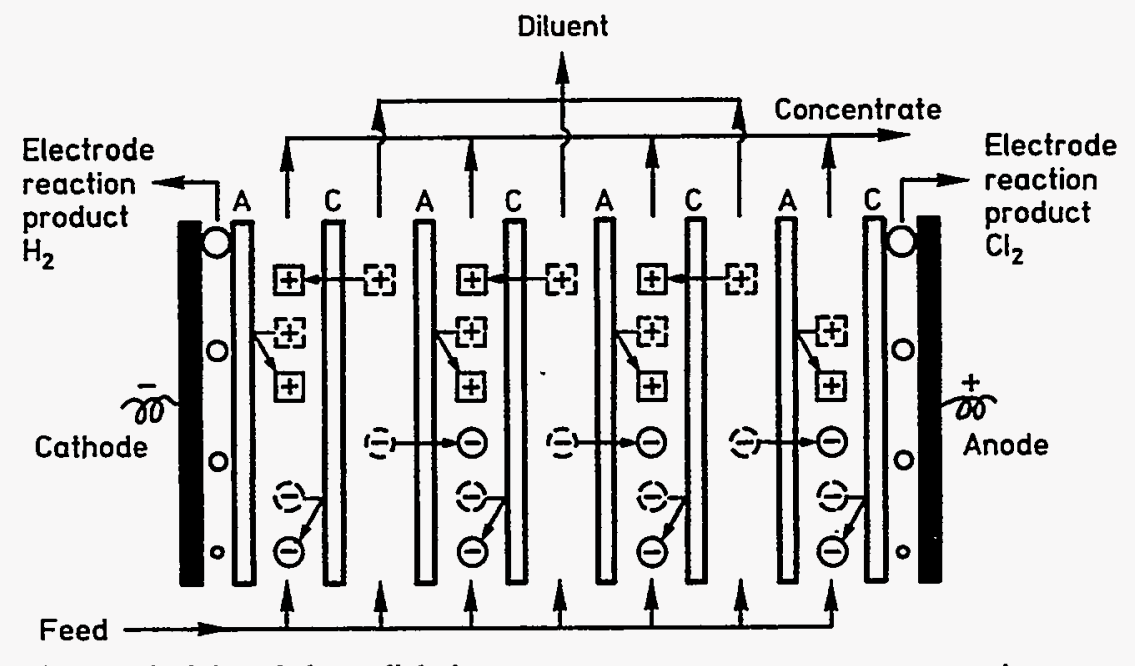

Fig. 3. Principles of electrodialysis

When an electric field is applied, the salts (ions) migrate towards the electrodes. Since each partition is permeable to only anions or cations, the sections become alternately depleted or enriched in salt ions. The imposed current drives the ions through the membranes, with cation membranes allowing passage of only positive charges, and anion membranes allowing only negative charges, leaving fresh water between them. The product water is withdrawn, while the brine is recycled. If the product quality is not acceptable, it is sent back for further desalting. Because of the different chemical reactions occurring at the electrodes, the products of the reaction must be removed, and the anode and cathode compartments rinsed and recycled. The water is the anode compartment is acidic due to the accumulation of hydrogen ions, while that in the cathode compartment. is alkaline due to the formation of hydroxyl ions, resulting in a high pH which accelerates scale formation. Process costs are directly related to the concentration of salt in the feedwater, i.e., the amount of current necessary to produce the separation. Electrodialysis also requires extensive pretreatment of the feedwater to reduce membrane degradation and fouling. For these reasons, electrodialysis is more cost effective for the desalination of brackish water than for sea water. Reverse osmosis and electrodialysis are both fairly efficient in the transfer energy but suffer in effectively separating the salt from sea water. Both processes over time produce concentration gradients near the membrane, which lowers the transfer efficiency. Pretreatment of the feedwater is mandatory in both cases to maintain efficiency.. Reverse osmosis pretreatment is usually more elaborate that that required for distillation. To date reverse osmosis systems are the most cost effective for desalination of brackish water. 
Summary of Desalination Processes:

The energy requirements and cost/gal of fresh water output for the various processes are listed in Table 1. The data is derived from desalination plants in use around the world.

\section{Table 1:}

Energy/Cost Comparison of Various Desalination Processes

\begin{tabular}{|c|c|c|c|c|c|c|}
\hline Process: & Feed & $\begin{array}{l}\text { Capacity: } \\
\text { (mgd) }^{1}\end{array}$ & $\begin{array}{l}\text { Energy required : } \\
\text { (kwh/kgal) }\end{array}$ & $\begin{array}{l}\text { Cost: } \\
\text { (\$/kgal) }\end{array}$ & Location & Ref. \\
\hline \multicolumn{2}{|c|}{$\begin{array}{l}\text { Multistage Flash Distillation (SW) } \\
\text { (MSF) }\end{array}$} & 6 & $12-22$ at $<90 \mathrm{C}$ & $7.0-9$ & U.A.E. & 4 \\
\hline (MSF) & $(\mathrm{SW})$ & 6 & $7-12$ at $90-121 \mathrm{C}$ & 4.9 & U.A.E. & 5 \\
\hline (MED) $w / T^{2} C^{3}$ & (SW) & 8.5 & 10 at $65 \mathrm{C}$ & 5 & U.A.E. & 6 \\
\hline$(\mathrm{MVC})$ & (SW) & 0.5 & $30-40$ & $7.0-10$ & U.A.E. & 78 \\
\hline Reverse Osmosis (RO) & (SW) & 4.4 & $36-48$ & $3.5-8.5$ & USA\&UAE & 9 \\
\hline (RO) & $(B W)^{4}$ & 10 & $7.0-14$ & $3.5-8.5$ & USA\&UAE & 10 \\
\hline (RO) & (SW) & 1.2 & 47.3 w/o E recovery & 8.7 & Kuwait & 11 \\
\hline (RO) & $(\mathrm{SW})$ & 1.2 & $35 \mathrm{w} / \mathrm{E}$ recovery & 8 & Kuwait & 12 \\
\hline (RO) & (SW) & 0.5 & & $5.0-6.6$ & Kuwait & 13 \\
\hline (RO) & $\begin{array}{l}(\mathrm{BW} \\
2100 \mathrm{ppm})\end{array}$ & 0.15 & 7 & 0.52 & USA & 14 \\
\hline (RO) & $\begin{array}{l}(\mathrm{BW} \\
1600 \mathrm{ppm})\end{array}$ & 0.5 & 8.5 & $1.1-1.4$ & Canada & 15 \\
\hline Electrodialysis (ED) & $(\mathrm{SW})$ & 0.025 & $60-75$ & & Iraq & 16 \\
\hline$(E D)$ & $\begin{array}{l}(\mathrm{BW} \\
11,000 \mathrm{ppm})\end{array}$ & 4 & $26-37$ & & Iraq & 17 \\
\hline (ED) & $\begin{array}{l}(\mathrm{BW} \\
1600 \mathrm{ppm})\end{array}$ & 0.5 & 7.7 & $\$ 0.91$ & Canada & 18 \\
\hline (ED) & $(\mathrm{SW})$ & 0.13 & 66.5 & & India & 19 \\
\hline (ED) & $(\mathrm{SW})$ & 0.15 & 70 & 17.9 & India & 20 \\
\hline (ED) & (BW) & 0.25 & & 1.20 & USA & 21 \\
\hline
\end{tabular}

\footnotetext{
${ }^{1} \mathrm{mgd}$ - million gallons per day

${ }^{2} \mathrm{SW}$ - sea water $(\sim 35,000 \mathrm{ppm})$

${ }^{3}$ TVC - thermal vapor compression

${ }^{4} \mathrm{BW}$ - brackish water $(-10,000 \mathrm{ppm})$
} 
Pre and Post Treatment of Process streams:

In order to operate a reliable and economical desalination plant, the feedwater is usually analyzed and pretreated. The quality of the water, whether brackish or sea water, is affected by seasonal variations in salt content, temperature, and turbidity (suspensions of particulate matter or microorganisms). Processes such as chlorination, filtration, softening, coagulation, acidification, dearation, etc. may be employed to minimize algae growth, scaling and corrosion of components. Of major economic concern is scale formation, which results from the following reactions:

$$
\begin{aligned}
& 2 \mathrm{HCO}_{3}^{-}=\mathrm{CO}_{3}^{-2}+\mathrm{CO}_{2} \uparrow+\mathrm{H}_{2} \mathrm{O} \\
& \mathrm{Ca}^{+2}+\mathrm{CO}_{3}^{-2}=\mathrm{CaCO}_{3} \downarrow \\
& \mathrm{H}_{2} \mathrm{O}+\mathrm{CO}_{3}^{-2}=2 \mathrm{OH}^{-}+\mathrm{CO}_{2} \uparrow \\
& \mathrm{Mg}^{+2}+2 \mathrm{OH}^{-}=\mathrm{Mg}(\mathrm{OH})_{2} \downarrow \\
& \mathrm{Ca}^{+2}+\mathrm{SO}_{4}^{-2}=\mathrm{CaSO}_{4} \downarrow
\end{aligned}
$$

The precipitating salts have inverted solubility's, i.e. increases in temperature favor precipitation (product denoted by $\downarrow$ ) or "scale" formation. In the case of $\mathrm{CaCO}_{3}$, the increase in temperature drives off the $\mathrm{CO}_{2}$ to favor the formation of $\mathrm{CaCO}_{3}$ (reactions \#1 \& 2). An increase in $\mathrm{H}^{+}$ions will prevent the second reaction by converting $\mathrm{CO}_{3}^{-2}$ to $\mathrm{HCO}_{3}{ }^{-}$ions and will reverse reaction 4 . As a result the hydroxide and carbonate scale formation is prevented by controlling the $\mathrm{pH}$, using an acid such as sulfuric or hydrochloric. However, acid dosing adds cost to the operation and the resulting low $\mathrm{pH}$ accelerates corrosion. The change in insolubility of $\mathrm{CaSO}_{4}$ with increasing temperature is far more of a problem, as is the increase in concentration. The precipitation calcium sulfate in a sea water desalination plant must be avoided because $\mathrm{CaSO}_{4}$ scale, once it is formed, can only be removed manually, because of its low solubility in acids. Saturation of a solution of $\mathrm{CaSO}_{4}$ results in the formation of three crystal forms with differing solubility's, anhydrite $\mathrm{CaSO}_{4}$, hemihydrate $\mathrm{CaSO}_{4} \cdot \frac{1}{2} \mathrm{H}_{2} \mathrm{O}$, and dihydrate $\mathrm{CaSO}_{4}$. The limited solubility of all three forms of calcium sulfate restricts distillation temperatures to $120 \mathrm{C}$ and concentration factors to less than two. The removal of calcium and sulfate ions from sea water would permit higher evaporation temperatures, up to $180^{\circ} \mathrm{C}$ and concentration factors of 5 . Several-methods have been devised to control sulfate scale. One method suspends seed crystals of $\mathrm{CaSO}_{4}$ in the evaporating salt solutions, or another, termed contact-stabilization, passes the brine through a bed of crystals outside the evaporator. ${ }^{22}$ The results from both methods show some improvement in $\mathrm{CaSO}_{4}$ scale prevention, but are somewhat inconclusive. Promising experiments were also carried out by Donath ${ }^{23}$ using anion and cation exchange columns. Using ion exchange to soften (the removing of $\mathrm{Ca}^{++}$and $\mathrm{Mg}^{+}$), and the removal of sulfate from sea water, an almost pure $\mathrm{NaCl}$ solution is obtained, which can then be fed to an evaporator. The evaporator brine can then be used directly to regenerate the ion exchanger. Scale formation research continues, as it remains a limiting factor to an inexpensive sea water desalination process.

The distillate or permeate from the desalination process is not suitable as potable water and must be posttreated. The low concentration of calcium and bicarbonate ions in the evaporator distillate in particular, in the presence of even small amounts of $\mathrm{CO}_{2}$ can be very corrosive. Posttreatment involves re-establishing the salt content and monovalent to bivalent ion ratio by the addition of calcium, bicarbonate and $\mathrm{pH}$ will neutralize the water, and chlorination, aeration and recarbonation make the water more appealing for taste and health reasons. 
None of the above mentioned desalination processes can be called a clear winner. Some are better suited for one situation over another, with the applicability determined primarily by the salinity and feedwater composition. The two processes best suited for sea water desalination are distillation and reverse osmosis. For brackish water desalination, reverse osmosis and electrodialysis are better alternatives. The most suitable technology for desalination at a particular location is driven more by site specifics. The selection is often based on a cost study, estimating fixed or capital costs of materials and equipment plus operating expenses. The parameters which typically affect the costs are capacity, process, feedwater salinity, feedwater quality, location, design, energy, materials, intake and disposal system. Research continues on new processes and modifications of existing ones, with the success relying on the economic viability and the hope is that further research will lead to lower costs.

\footnotetext{
${ }^{1}$ Principles of Desalination, K.S. Spiegler, Ed., 1966, Chap 1, "Desalination Research and Water Resources", Gilliam, W.S., McCoy, W.H., p 1-20.

${ }^{2}$ Ibid.

${ }^{3}$ Murphy, G.W. (1956) Office of Saline Water Res. and Develop. Progr. Rept. 9.

${ }^{4}$ Desalination Processes and Multistage Flash Distillation Practice, Arshad Hassan Khan, TD 479 K48 (1986).

${ }^{5}$ Ibid.

${ }^{6}$ Wade, N.M., Desalination, 93, 343-363, (1993).

${ }^{7}$ Ibid.

${ }^{8}$ Ebrahim, S., Abdel-Jawad, M., Desalination, 99, 39-55, (1994).

${ }^{9}$ Desalination Processes and Multistage Flash Distillation Practice, Arshad Hassan Khan, TD 479 K48 (1986).

${ }^{10}$ Ibid.

${ }^{11}$ Al-Zubaidi, A.A.J., Desalination, 76, 241-280, (1989).

${ }^{12}$ Ibid.

${ }^{13}$ Fosselard, G., Wagnick, K., Desalination, 76, 215, (1989).

${ }^{14}$ Practice of Desalination, Bakish, Robert, Ed. TD433 B2 (1971).

${ }^{15}$ Harries, R.C., et al., Desalination, 84, 109-121, (1991).

${ }^{16}$ Desalination Processes and Multistage Flash Distillation Practice, Arshad Hassan Khan, TD 479 K48 (1986).

${ }^{17}$ Ibid.

${ }^{18}$ Harries, R.C., et al., Desalination, 84, 109-121, (1991).

${ }^{19}$ Adhikary, S.K., Narayanan, P.K., Thampy, S.K. etal., Desalination, 84, 189-200, (1991).

${ }^{20}$ Narayanan, P.K., Thampy, S.K., Dave, N.J., et.al., Desalination, 84, 201-211, (1991).

${ }^{21}$ Principles of Desalination, Spiegler, K.S., Ed., Chap 1, TD 433 S1 (1966).

${ }^{22}$ Langelier, W.F., Caldwell, D.H., Lawrence W.B., Ind. Eng. Chem. 42, 126-130, (1950).

${ }^{23}$ Donath, G. "Aufbereitung von Meerwasser Mit Ionenaustauschern", Vom Wasser, 61, 237-238, (1983).
} 


\section{DISCLAIMER}

Portions of this document may be illegible in electronic image products. Images are produced from the best available original document. 